\section{МЕНТАЛЬНОСТЬ КАЛМЫКОВ: ИСТОКИ И ПРИЧИНЫ ИЗМЕНЕНИЙ}

\author{
Любовь Б. Четырова \\ Самарский национальный \\ исследовательский университет \\ имени академика С. П. Королева, \\ Россия
}

В статье анализируется вопрос об истоках и особенностях ментальности калмыков. Обосновывается положение о военном происхождении важных для калмыков категорий чести и достоинства. Рассматривается, как изменение исполняемых ими практик приводило к изменению ментальных структур. Анализ осуществлен с применением теории габитуса П. Бурдье, а также феноменологии чужого (Э. Гуссерль, Э. Левинас, Б. Вальденфельс, А. Шюи).

Выделены ключевые моменты в истории калмыков, оказавшие влияние на формирование и изменение калмыцкой ментальности: вхождение в Российскую империю, расцвет Калмыцкого ханства, уход большей части калмыков в Джунгарию, формирование управленческих и хозяйственных структур в пост-ханский период, широкомастабное отходничество, начавшееся с середины XIX в., события двух революций, советский проект модернизации, война и ссылка в Сибирь, восстановление автономии, постсоветский период.

Ментальность калмыков исследуется в империологической рамке, позволяющей рассмотреть фор-

\section{THE MINDSET OF KALMYKS: ORIGINS AND CAUSES OF ALTERATIONS}

\author{
Liubov B. Chetyrova \\ S. P. Korolev Samara National \\ Research University, \\ Russia
}

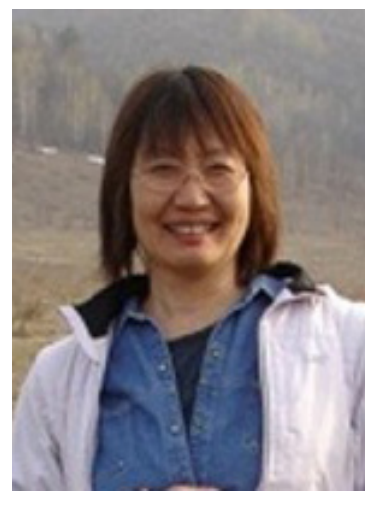

The article examines the issue of origins and specific features of the mindset of Kalmyks. The categories of honor and dignity, very important for Kalmyks, are proved to be of military origin. The article traces how a change in Kalmyk practices led to corresponding alterations in menthal structures. Our analysis in the theoretical aspect is based on the theory of habitus developed by P. Bourdieu and phenomenology of the Other (Alien) as explicated by E. Husserl, E. Lévinas, $B$. Waldenfels and A. Schütz.

The author highlights several key moments in the history of Kalmyks that helped shape and alter the mindset of Kalmyks, such as annexation to Russian Empire, the heyday of Kalmyk Khanate, the relocation of the majority of Kalmyks to Dzungaria, the rise of administrative and economic structures in post-khanate period, large-scale departure for seasonal works in mid-19th century, two revolutions, the Soviet modernization project, WWII and the deportation to Siberia, the subsequent restoration

\footnotetext{
"Статья написана при финансовой поддержке РФФИ, грант «Аккультурация нерусских: имперские проекты и повседневная практика», № 15-31-01007.

The article was written as part of the project financially supported by Russian Foundation for Basic Research, grant "Acculturation of non-Russians: Imperial projects and routine practices", No. 15-31-01007

Четырова Любовь Борисовна - доктор философских наук, профессор кафедры философии Самарского национального исследовательского университета имени академика С. П. Королева. Адрес: 443086, Россия, г. Самара, Московское ш., д. 34. Тел.: +7 (846) 335-18-26; +7 (846) 337-9954. Эл. адрес: chetyrova@gmail.com

Chetyrova Lyubov Borisovna, Doctor of Philosophy, Professor, Chair of Philosophy, S. P. Korolev Samara National Research University. Postal address: 34 Moskovskoye Shosse, Samara, Russian Federation 443086. Tel.: +7 (846) 335-18-26; +7 (846) 337-99-54. E-mail: chetyrova@gmail.com
} 
мирование и трансформации ментальности калмыков как имперского народа. Этногенез ойрат происходил в военно-политическом пространстве Монгольской империи, формирование калмыков как этноса осуществлялось в этнополитическом пространстве Российской империи, а формирование калмыков как нации происходило в составе советской «империи наций» - СССР. Показано, что конструирование новой нации и идентичности калмыков в постсоветский период оказало воздействие на их ментальность.

Эмпирическую основу статьи составляют документы из Национального архива Республики Калмыкия, литературные источники дореволюцзионного периода, периодика раннесоветского периода.

Ключевые слова: ментальность; габитус; феноменология чужого; кочевники; калмыки; Калмыкия; советская модернизация; аккультурация of autonomy, and finally, the post-Soviet period.

The article analyzes the mindset of Kalmyks is analyzed within the framework of Empire studies, which allows to focus on the evolution and alterations in mindset of Kalmyks as an imperial ethnos. Ethnogenesis of Oyrats occurred within the military and political domain of Mongol Empire, Kalmyks as ethnos arose in the ethnopolitical landscape of Russian Empire, and Kalmyks as nation appeared within the "empire of nations" USSR. The author shows that the construction of a new nation and identity of Kalmyks in the postSoviet period also affected their mindset.

The article is based on the studies of the documents preserved at the National Archive of the Republic of Kalmykia, pre-revolutionary literature and periodicals of the early Soviet period.

Keywords: mindset; habitus; phenomenology of the alien; nomads; Kalmyks; Kalmykia; Soviet modernization; acculturation

\section{Введение}

Россияне, как известно, этнически и культурно весьма пестрый народ. На вопрос: «Как дела?» часто в ответ можно услышать сетования на жизненные трудности. Калмык же, как бы худо не обстояли у него дела, ответит: «А-a-a, пойдет!» Подобная оптимистичность исходит из особенностей ментальности калмыков.

Изучение ментальности вообще, а этнической ментальности в особенности, чрезвычайно интересное и актуальное направление научных исследований. Унификация культур в глобальном мире вызвала реакцию со стороны относительно небольших этнических групп, опасающихся за сохранение их культур.

Изучая ментальность тюрко-монгольских народов, живущих в современной России, следует помнить о том радикальном повороте, который произошел в их истории в советский период, когда они стали оседлыми. Разрыв с кочевническим прошлым, с его хозяйственными и культурными практиками, несомненно, способствовал трансформации ментальности этих народов. Важным в понимании ментальности тюрко-монголов является тот факт, что их форматирование в качестве этнических групп/этносов, происходило в матрицах империй прошлого - монгольской, российской, советской «империи наций». А в случае с калмыками нужно помнить, что своеобразие их ментальности определяется опытом их принадлежности и к русскому, и к монгольскому миру, к Европе и Азии. Калмыки являются в буквальном смысле евразийцами - будучи азиатами, живут на территории Европы. 
Цель статьи - изучение истории формирования ментальности калмыков, ее трансформации в матрице государств-империй. Иначе говоря, в мою задачу входит исследование транзитивности ментальности калмыков, прошедших путь от воинов-всадников до оседлых жителей городов и сел.

Наиболее подходящими методологическими инструментами для изучения ментальности как содержания и строя мыслей, на мой взгляд, являются теория габитуса П. Бурдье (Бурдье, 2001: 43-44). В статье будет также будет использована концепция чужого, разработанная И. В. Пахоловой в русле исследований феноменологии чужого (Пахолова, 2011: 61-64).

\section{Этногенез ойрат: воины Монгольской империи}

Ойраты ${ }^{1}$ после падения Монгольской империи и ее раскола на отдельные государства стали наиболее могущественными кочевниками в степях Центральной Азии (Lee, 2016: Электр. ресурс). По мнению Р. Груссе, они были, вероятно, последним из правящих имперских народов в Центральной Азии в период с XVI по XVIII в. (Grousset, 1980: 10). Им удалось создать три кочевых империи, весьма значимых в политическом и религиозном ландшафте указанного периода Джунгарское, Хошутское (Кукунорское) и Калмыцкое (Grousset, 1970: 520-540). Торгуды, пройдя путь Бату-хана, пришли на нижнюю Волгу и основали Калмыцкое ханство (там же: 540). Калмыки приняли активное участие в строительстве Российской империи, завоевывая и отстаивая для рождающейся империи территории Северного Прикаспия и Кавказа, а также Среднего Поволжья, которое в XVII-XVIII вв. стало «внутренней окраиной» России (Поволжье ..., 2007).

Происхождение этнических групп ойрат связано с военными подразделениями Чингис-хана 2 . Как полагает В. Санчиров, торгуды как этническая группа возникли на основе имперской гвардии Чингис-хана туркак-кешигтен (turqaq kesikten) (Санчиров, 1996: 36-37). Чингис-хан создал элитное гвардейское подразделение из своих наиболее лояльных союзников, которые рекрутировались из разных племен. Членство в гвардии расценивалось как высочайшая честь

\footnotetext{
${ }^{1}$ Ойраты или лесной народ, живший до вхождения в состав империи Чингис-хана в Восьмиречье у истоков Енисея, по Селенге и северной части Байкала, являются предками калмыков. Войдя в состав Монгольской империи, ойраты позднее дифференцировались на разные этнические группы торгудов, элетов, хошутов, дербетов и др. Одна из ойратских этнических групп - торгуды откочевала и вошла в состав русского государства в начале XVII в. Немного позже к ним присоединились дербеты и некоторые другие этнические группы ойрат. На основе этого этнического субстрата появились калмыки. Данный этноним тюркского происхождения, так называли откочевавших в Россию ойрат казахи и другие тюрки (Митиров, 1998: 37-85). Долгое время ойраты сохраняли субэническую идентификацию, называя себя торгудами или дербетами. Впервые в письменных источниках этноним «калмык» применительно к своим подданным употребил наместник ЦеренДондук, сын Аюки-хана.

${ }^{2}$ Подробную этническую историю ойратских групп описывает С. Хойт (Хойт, 2015: Электр. ресурс).
} 
(Lane, 2006: 97). Этимология другого ойратского этнонима «хошут» связана со значением «порядок построения войск клином» (Бакаева, 2017: Электр. ресурс). Г. О. Авляев и В. П. Санчиров доказывают, хошуты как этническая группа появились из воинов подразделения авангарда монгольского войска (Авляев, Санчиров, 1984). Поскольку данные этнические группы возникли на основе военных подразделений, то, этос, свойственный воинам, стал матрицей, порождающей категории, характеризующие ментальность ойрат.

Ойраты вели военно-кочевой образ жизни, а значит, их основными практиками были военные и, соответственно, категории восприятия, которыми они руководствовались, были также военными. Об этом можно судить на основании «Иэке цааджин бичиг» или «Великого уложения» - закона, принятого в 1640 г. Согласно этому закону, для борьбы с маньчжурскими завоевателями мобилизуется все население Монголии и Джунгарии от владетельных князей до простолюдинов. K тем, кто уклонялся от мобилизации, применялись самые суровые наказания смертная казнь, конфискация имущества, штрафы (Голстунский, 1880: 36-39).

Статьи Великого Уложения формулируются в той правовой парадигме, которая сложилась со времен Великой Ясы. Арабский историк Джувейни так описывает особенности монгольского войска и монгольских воинов: «Это войско подобно крестьянству, что выплачивает разные подати и не выказывает недовольства, чего бы от него ни требовали, будь это копчур, специальные налоги, содержание проезжающих, почтовых станций с предоставлением лошадей и корма для них» (Чингис-хан ..., 2004: 23). Джувейни подчеркивает, что монгольское войско одновременно было хозяйственной структурой. Он называет монголов крестьянами «в образе войска», которые «все как один, от мала до велика, от знатного до низкого, во время сражений рубят саблями, стреляют из луков и колют копьями и способны свершить все, что ни потребуется. Когда бы ни ставилась задача уничтожить неприятеля или усмирить бунтовщиков, они приготовляют все, что потребуется в этом случае, от различного оружия и снаряжения до знамен, иголок, веревок, верховых и вьючных животных, таких как ослы и верблюды» (там же: 23).

«Великое уложение» закрепляло подчинение простолюдинов князьям: «Кто (во время войны) избавит князей (от опасности), того сделать дарханов в дивизии; кто покинет (во время опасности), того убить, разорить» (там же: 38). Здесь лежат корни почитания вышестоящих - черты, которую отмечали все писавшие о калмыках в XIX в. Закон воспрещал кочевникам занимать нейтральное положение и быть вне военного противостояния: «Кто увидит или услышит о значительном неприятеле и не сообщит, того, изгнавши с потомками потомков, убить, разорить» (там же: 38). Иначе говоря, закон принуждал кочевников к участию в военных действиях. Нельзя было оставаться просто мирным пастухом своих стад: «Если будет тревога, то должны собираться около князей; кто услышит тревогу и не явится, то да будет поступлено с тем по вышеозначенному положению» (там же: 38). А это означало - либо крупный штраф, либо 
смертную казнь. Такими жесткими мерами у ойрат формировались дисциплинированность и послушание, необходимые для воина.

В калмыцком обществе воинами были и люди белой кости (т. е. благородного происхождения), и простолюдины. Харчуд - человек черной кости (т. е. простолюдин) был одновременно и воином, и трудящимся. Такой статус, несмотря на полную зависимость простолюдинов от своих владельцев, сформировал нормы демократического этоса: «Калмык покорен без унижения. Если он просит о чемнибудь, то говорит просто, не зная поклонов и не изменяя ни вида, ни голоса, так, что просьба его бывает более похожа на требование» (Нефедьев, 1834: 362). Этнограф отмечает демократизм отношений в калмыцком обществе, в котором беднейший гость принимается наравне с богатым: «Бедные калмыки никогда не ходят за милостыней, а находят средства в своих хотонах» (там же: 368).

В силу своего основного занятия - воинского дела, у ойратских воинов сформировались категории, важнейшими среди которых являются гордость и честь. Если обратиться к Великому Уложению, то здесь особо оговариваются штрафы, которые налагались за посягательства на предметы, имеющие для калмыков особый символический смысл. Например, за телесные повреждения, вроде выдирания бороды, штраф был меньше, чем за выдирание кисточки на шапке: «Кто издерет на ком-либо платье, с того взять двухлетнего жеребенка; кисть на шапке и коса имеют (цену) пяти (скотин); (за выдирание) бороды взять лошадь и овцу» (Голстунский, 1880: 49-50).

Следовательно, военно-кочевой образ жизни и закон, регулирующий отношения в калмыцком обществе, способствовали формированию ментальности, свойственной воинам.

У всадника, исполняющего военные практики, формируется вполне определенный габитус как система принципов, организующих действия. Введенное П. Бурдье понятие габитуса выражает, с одной стороны, предопределенность действий человека, на которого влияют такие детерминанты, как символический и экономический капитал, род занятий, нормы группы/сообщества, к которой индивид принадлежит, социальные связи, в которые он включен, особенности его биографии. Эти детерминанты определяют манеру человека держаться, мыслить и говорить (Бурдье, 1993: 57). Габитус в данном случае обозначает инкорпорированные схемы действия, функционирующие как категории восприятия и оценки, как принципы классификации социального мира (Козлова, 1999: 40). С другой стороны, габитус выступает как система принципов, порождающих разные практики. Человек, в данном случае выступает как социальный агент, конструирующий свою реальность (Бурдье, 1994: 99-100).

Итак, военные практики, исполняемые калмыками, определили формирование их габитуса воинов и, соответственно, формирование черт воинской ментальности. 
Значимость для кочевников категорий чести и гордости способствовала тому, что они стали важнейшими ценностями. Наряду с этими важными ценностями были такие, как род и семья. Каждый калмык обязан был знать своих предков до седьмого колена. Д. Армстронг, исследуя различия между идентичностью кочевников и оседлых, предлагает использовать при анализе их мифы и символы. Изучив их, он приходит к выводу, что обе группы и их идентичности основаны на несовместимых принципах. Территориальный принцип стал преобладающим в Европе, а генеалогический - на Ближнем Востоке (Armstrong, 1982: 11). Полагаю, что на генеалогическом принципе строится идентичность всех кочевников, не только тех, кто жил на Ближнем Востоке.

Особенность бытия кочевника заключается в том, что он укоренен во времени - в веках, а не в пространстве, как земледелец. Приоритет ценности рода во многом определялся территориальной неукорененностью кочевника.Отсутствие привязки к одной и той же местности раздвигало территориальные границы и создавало некоторую неопределенность в жизни кочевника. Эта неопределенность снималась установлением порядка на основе знаний о роде, о своем месте в системе родства. Так обеспечивалась строгая определенность и порядок жизни. Если у европейцев, к примеру, древность рода была признаком аристократизма, то у кочевников древность учитывалась всеми членами общества. Калмыки, как представители белой кости, так и простолюдины, заботились о знании своей родословной. Знание родословной было тем более необходимым, что брачные стратегии у калмыков основывались на принципе строгой экзогамии.

Таким образом, ментальность калмыков формировалась в ходе реализации практик, как профессиональных - исполнение воинского долга, так и практик семейно-брачных, хозяйственных и иных.

\section{Вхождение в Российскую империю. Чужие и свои}

Дальнейшая трансформация ментальности калмыков происходила в ходе их аккультурации, начавшейся с момента их территориального, а затем политического вхождения в русское государство. Понять, какие этапы в этом длительном процессе были пройдены, нам поможет феноменология чужого.

«Чужое» И. Пахолова определяет как то, что отсутствует, то есть полагается, как отсутствующее. А это значит, что с ним нельзя разделить ни прошлое, ни настоящее, ни будущее. Кроме того, «чужое» не предполагает каких-либо отношений, что вполне закономерно. Ведь невозможно выстроить отношения с отсутствующим (Пахолова, 2011: 144-145). На самом первом этапе отношений с русскими калмыки действительно отрицали возможность установления какихлибо отношений, как об этом можно судить на основании описей сибирских архивов, составленных Г. Ф. Миллером (Миллер, 1993). 
Приблизившись к Волге, калмыки стали заключать с русским государством договоры - шерти ${ }^{1}$, которые, правда, неоднократно нарушались. Установление отношений символического обмена меняло статус Чужака, участники обмена становились «иными». «Иное», будучи неродным, с которым нет общего прошлого, тем не менее открывает возможность общего настоящего и будущего. Иной - это бывший Чужак, который пришел издалека и задержался надолго. От иноземца/иного уже будут ждать чего-то взамен, а сам иноземец будет бороться за социальное признание. Собственно, вся история Калмыцкого ханства и деяния калмыцких правителей были борьбой за это социальное признание. Сама же борьба осуществлялась в форме символического обмена.

Перипетии этой борьбы за социальное признание можно проследить, читая архивные документы и литературные источники. Повествуя о событиях, вызванных калмыцкой усобицей из-за ханской власти, в частности, о примирении наследников Аюки-хана, чиновник В. Бакунин пишет следующее: «Посланцы от хана крымского и Дондук-Омбо были у Черен Дондука с таким представлением, чтобы они «примирились не чрез россиян, но сами собою, что будет им в похвалу, а ежели будут они мириться чрез россиян, то будет им в бесславие, будто они приведены к тому от россиян неволею» (Бакунин, 1995: 101). Бакунин подчеркивает в своих записках такую черту, как гордость калмыцких владельцев. Исполнение требований политического этикета весьма чувствительно воспринимается сторонами политического диалога, так как нормы этикета регулируют знаковые формы выражения отношений господства/подчинения. Благодаря этим нормам властные отношения становятся визуальными. Если участники диалога равны в своем отношении к власти, то их действия и жесты равнозначны, если же один из участников диалога демонстрирует большую почтительность, то он обозначает себя как зависимую фигуру. Бакунин пишет о грамоте императрицы к калмыцкому владельцу Дондук-Омбо, ушедшему к крымскому хану. В грамоте императрица прощает его измену и склоняет к добровольному возвращению. Но обязательным условием было требование принять грамоту не «горделивым образом, а встав со своего места» (там же: 97; курсив мой. Л. Ч.). Но мятежный владелец и будущий наместник ханства Дондук-Омбо, ссылаясь на обычай, заведенный со времен его деда, отказался принимать грамоту стоя (там же: 102-103). Дондук-Омбо писал князю Черкасскому, что грамоту не принял, так как посланные им люди требовали, чтобы он принял ее стоя.

Такое поведение объясняется тем, что калмыки воспринимали царскую власть через призму своей собственной политической системы. Русский император был в их глазах только военным лидером и защитником, но не имел права вмешиваться в их административные и экономические дела. Калмыки по-

1 Термин, употреблявшийся в русской дипломатии с XV века, арабского происхождения, был заимствован тюрками и означал присягу на верность. 
лагали, что им будет позволено быть независимыми, хотя рассчитывали вместе с тем на финансовую и военную поддержку Москвы (Khodarkovsky, 1992: 239).

Борьбу за социальное признание можно проследить по деловой переписке ханов. Наместник Дондук-Омбо в письме астраханскому губернатору обращается к нему не иначе как к верному другу. Сам тон письма не просительный, а скорее приказной, «теперь дайте больще прежнего». Более того, он ставит выступление калмыков в зависимость от того, как скоро даст губернатор боеприпасы. А затем следует прямая угроза губернатору - пожаловаться императрице (Национальный архив Республики Калмыкия - далее НАРК. Ф. 36. Оп. 1, д. 85). Называя себя младшими братьями российского императора, ханы ревниво следили за тем, чтобы местные чиновники - губернаторы, например, обращались к ним с должным почтением. Они не считали их равными по статусу себе.

Калмыцкое ханство, существовавшее как автономия в составе Российской империи, к концу XVIII в. выполнило те задачи, которые перед ним ставились - освобождение от кочевников-аборигенов территорий Среднего и Нижнего Поволжья, Северного Прикаспия и Кавказа. Сильному калмыцкому войску, обладавшему иной техникой ведения боя, иным вооружением, уступали кочевникиаборигены Понизовья и Прикаспия. Империя была заинтересована в интеграции кочевников-калмыков в оседлую русскую культуру. В конечном итоге, потерпев поражение в притязаниях на социальное признание себя как кочевников, обладателей своей собственной автономной государственности, калмыки в лице наместника Убаши принимают решение покинуть пределы России. Откочевавшая часть калмыков в отношениях с русскими вновь обрела статус Чужака.

С оставшейся частью калмыков отношения символического обмена были продолжены. Когда они в качестве Иных получили признание в сообществе, тогда их границы расширились, впуская в себя Других. Структура отношений с Другим основана на общности истории и культуры, так как в нее инвестируется общее прошлое нескольких поколений (Пахолова, 2015: 92-93). У калмыков и русских появилась общая история, главными событиями которой были завоевания и защита территорий на юге России.

Самоликвидация Калмыцкого ханства в 1771 г. привела к тому, что калмыками стали управлять имперские чиновники. Интенсивность непосредственных контактов калмыков с русским населением и культурой усилились вследствие аграрного развития региона Нижнего Поволжья и Северного Кавказа. Это создавало конфликтную ситуацию, причиной которой была земля. Калмыкам, согласно размежеванию 1873 г., была отведена земля в Калмыцкой степи. Но на эту земля и после размежевания претендовали и казаки, и безземельные крестьяне, пришедшие с Украины и русских губерний. Именно конфликты из-за земли стали одной из главных причин неприязненного отношения русских к калмыкам. Переселенцы из русских губерний считали, что земля должна принадлежать им, а не кочевникам-нехристям. Земля должна обрабатываться, а 
не лежать впустую. То, что калмыки пасли на ней свой скот, в расчет не принималось. В массовом сознании безземельных крестьян идея христианизации, с помощью которой власти желали ассимилировать калмыков, видоизменилась самым причудливым образом. Этнограф Я. П. Дуброва так изложил ход мыслей крестьянина-переселенца: «пора православным сменить негодную тварь и образовать ее на крестьянский манер» (Дуброва, 1998: 35-36).

Наступление русского крестьянства на калмыцкие земли, появление арендаторства, а также периодически случавшиеся из-за эпизооотии и климатических катаклизмов (бураны, засуха) приводили к обеднению калмыков и широкому распространению отходничества. Тысячи калмыков работали на рыбных промыслах и солеломных работах. Статистические данные говорят о том, что в 1892 г. на 13 рыбных промыслах было занято 7639 калмыков (Очиров, 2008: 203). Сезонность характера работ позволяла калмыкам-отходникам сочетать скотоводство с наймом на работы.

Опыт столкновения с городской культурой для калмыков-отходников имел как позитивное содержание, так и негативное. Несомненно, позитивным влияние русского окружения было в части обретения калмыками навыков земледелия, заимствование приемов домоводства, усвоение гигиенических практик. Однако нельзя забывать о негативном влиянии городской культуры и приобретаемых в результате пороков - пьянства, азартных игр. Как считает В. В. Батыров, широкое развитие отходничество привело к маргинализации калмыцкого общества и ломке традиционной системы ценностей и институтов (Батыров, 2014: 186-187).

Калмыки постепенно утрачивали свой габитус воина. Те образы калмыков, которые рисуют в своих работах публицисты, ученые и писатели в конце XIX в. являются наглядной иллюстрацией процесса смены габитуса. Ставропольский краевед Г. Прозрителев, используя свой 30-летний опыт судебной практики, дает очень точную портрет калмыка. Калмык держит свое слово, незлопамятен, в нем сильно чувство «собратства», «содружества», неведомое, как он пишет русским. Своеобразное представление о чести и достоинстве у калмыков, заставляющее их на каторгу за «собрата», «близняка», которого они не желают выдавать. Калмыки не были замечены в кражах, мошенничестве. Исключение составляет скотокрадство, которое рассматривалось калмыками как молодечество. Угон скота, табуна лошадей был в глазах калмыков не преступлением, а проявлением отваги и доблести (Прозрителев, 1912: 3-12). Однако такие проявления молодечества расценивались русскими как воровство и калмыков со временем стигматизировали как «нечистых на руку людей». Так, в Самарской губернской газете в XIX в. появилась заметка, где описывалось как остроумный калмык, проделав дыру в кошме, на которой в поле спал крестьянин после трудов своих, привязал к ней аркан и полном скаку сдернул ее (Самарские губернские ведомости, 1854: 80-81). 
Прозрителев пишет о причинах деградации калмыков как воинов: «Нынешнее положение наших калмыков и их образ жизни не дают ни малейшего основания представить себе калмыков на боевом коне, на ратном поле, героем боевых подвигов» (Прозрителев, 1912: 3). Среди причин такого измельчания калмыков он называет «нескончаемые войны, которыми сопровождался уклад гражданских отношений на Кавказе» (там же).

С горечью о деградации калмыков писала в своей повести «Утбалла» Елена Ган, дочь Главного попечителя Калмыцкого народа А. П. Фадеева (1835-1839) и мать основательницы теософии Е. П. Блаватской. Повесть, написанная под псевдонимом «Зинаида Р-ва», была высоко оценена В. Белинским (Р-ва, 1838). Благодаря деятельности отца и этнографическим изысканиям своей матери Е. П. Фадеевой, коллекции и труды которой высоко оценивали ученые, она хорошо знала быт калмыков и их культуру.

Публицист В. И. Немирович-Данченко писал о калмыках следующее: «Смелые и вольнолюбивые калмыки обратились в жалких париев, обобранных нойонами, ограбленных гелюнгами, и раздавленных, насколько это возможно, русскими властями. Тип калмыка теперь - это общий тип приниженного раба. Говоря с вами, он робко опускает глаза. Ежится как-то, словно старается и ростом стать ниже. Он как бы постоянно чувствует себя виноватым» (Немирович-Данченко, 1887: 336).

Тысячелетняя история кочевника «отпечаталась» в его теле и проявляется в кривизне его коротких ног, цепляющихся за лошадиные бока, длинном туловище и прямой спине. Здесь дело не только в генетике. Бурдье говорит не просто о теле, а о теле, освоенном историей. Телесный язык кочевника, его жесты кочевника, мимика, позы определяются его неразрывным единством с конем. Сетуя на тяжелую жизнь калмыков, П. Огородников с большой симпатией пишет о них: «Жизнь их очень тяжела... А всмотритесь в этого коренастого, с выгнутыми от езды ногами, калмыка - вот с олицетворить бы дикую силу, истязаемую плетью мачехи-судьбы!.. Он здесь в городе ежится, не смел, а посмотрите на него в степи, когда он вихрем мчится на диком коне, - вам кажется, что он прирос к нему!» (Огородников, 1878: 42-43). Калмык и его конь представляли собой единое целое. Слезая с коня, калмык, как отмечали многие этнографы, двигался пешком не очень уверенно.

Попав в иную среду, «сошедшие с коня», неуверенно стоящие на земле, не владеющие хорошо русским языком, почитающую власть в любых ее проявлениях калмыки, производили впечатление робких и приниженных людей. Впечатление от этого образа усиливалось тем, что калмыки казались другим простодушными, доверчивыми людьми, которых легко обмануть. То, что казалось простодушием и доверчивостью, сформировалось у калмыков благодаря буддийской практике. Для калмыков-буддистов ложь и злословие были одними из 
десяти не благих деяний - грехов ${ }^{1}$. Важными среди принципов классификации социального мира, категорий восприятия и оценки, определявших схемы действий, были буддийские.

Таким образом, маргинализация, начавшаяся у калмыков со второй половины XIX в., сопровождалась изменением их ментальности. Утрачивая габитус воина, они утрачивали категории прежнего военного происхождения.

\section{«Империя наций» и формирование советской ментальности}

Радикальный перелом в жизни кочевников-калмыков наступил после Великой Октябрьской революции. Степная экономика была практически полностью разрушена в ходе гражданской войны. Согласно переписи 1920 г. по сравнению с 1916 г. в Калмыкии осталось всего 5\% лошадей, 15\% верблюдов, 23\% крупного рогатого скота и 80\% мелкого. Из 34073 хозяйств области 10545 совершенно не имели скота, 21784 не имели рабочего скота, а в 12472 хозяйствах не было коров (Очерки ..., 1970: 90). По данным Областного статистического бюро, в 1926 г. было всего 6\% семей, имевших от 15 до 30 голов необходимых для выживания скота. Но таких хозяйств среди калмыков было всего 6\% (Лебединский, 1927: 134). Выжить в этой ситуации калмыки могли, лишь сменив скотоводческий образ жизни на оседлый и, соответственно, радикально поменяв все свои практики, начиная с хозяйственных и заканчивая гигиеническими. Смена же исполняемых практик означала смену габитуса и, в конечном счете, ментальности, так как менялись категории восприятия и оценивания.

Проблема «чужого» и своего «другого» в отношениях русских и калмыков была переопределена в советском дискурсе аккультурации. В Российской империи, в которой идентичность российских подданных устанавливалась с помощью религии - православия, условием интеграции нерусских была их христианизация. В случае с калмыками - буддистами в подавляющем большинстве, «чужесть» усиливалась тем, что буддизм рассматривался как религия иностранного происхождения. В новых условиях идентичность советских граждан определялась их классовой принадлежностью, а религия рассматривалась как пережиток прошлого и репрессируемый институт. Сложность для большевиков состояла в том, что, создавая новую многонациональную советскую культуру, они вместе с тем создавали акторов, строящих ее. Если в имперский период доминирующей была русская культура, в основе своей православная, а русский народ - господствующей нацией, то в советское время доминирующей должна была стать многонациональная советская культура, в которой не должно было

\footnotetext{
1 Три относятся к неблагим деяниям тела - убийство, воровство, прелюбодеяние; четыре - к деяниям речи: ложь, сквернословие, злословие и пустословие; три к деяниям ума - алчность, злонамеренность, приверженность ложным воззрениям (Далай лама ..., 2009: Электр. ресурс).
} 
быть доминирующей нации. И русский народ, и нерусские народы прошли период форматирования в матрице советского государства, которое строилось как новая империя - империя вновь создаваемых наций (Hirsch, 2005).

Модернизация хозяйственной жизни осуществлялась среди калмыков путем перевода их на оседлый образ жизни. В 1926 г. была разработана программа по «обоседлению» (седентаризации).

Другим направлением модернизации была культурная революция. Важнейшими задачами культурной революции были ликвидация неграмотности, формирование социалистического мировоззрения, создание социалистической культуры. По данным Всесоюзной переписи населения 1926 г., на 1 тысячу населения приходилось 17,3\% грамотных, или 24,1\% грамотных мужчин и 10,3\% - женщин (Всесоюзная..., 1926: Электр. ресурс). Конечно, это гораздо больше, чем было до революции, когда лишь 3,7\% калмыков были грамотными (История Калмыкии, 2009: 363). Однако существенно ниже, чем в среднем по европейской части России, к которой относилась Калмыкия - 58,2\% грамотных мужчин и 33,4\% женщин (Всесоюзная..., 1926: Электр. ресурс).

Причем калмыцкие женщины преуспели в получении образования и смене образа жизни, одежды гораздо больше, чем их товарки-мусульманки.

В области партийно-государственного строительства в национальных регионах в 1920-е годы особое внимание уделялось коренизации партийного, советского и хозяйственного аппаратов, школ и культурных учреждений. Коренизация была нацелена на интеграцию калмыков, как и других нерусских народов в создаваемую систему управления - политического, хозяйственного, культурного сфер управления.

Поскольку калмыки в массе своей не владели русским языком, то эффективно управлять ими можно было при наличии в административном аппарате калмыков. Калмыцкий облисполком 30 декабря 1926 г. создал специальную комиссию, перед которой была поставлена задача коренизации личного состава государственного аппарата и перевода делопроизводства на калмыцкий язык. Аппарат нужно было создавать из коренного населения (НАРК. Ф. И-115. Оп. 1. Д. 121). К примеру, на 1 января 1927 г. партийная организация Калмбазаринского улуса составила 80 человек, из которых 51 человек - калмыки. Руководящий состав был из калмыков (Михайловский, 1928: 71). Политика коренизации сопровождалась эффектом роста этнического самосознания калмыков. Национальная политика советского государства была ориентирована на формирование субъекта из разнородных этнических групп, населяющих пространство огромной империи. Советские республики стали той политической рамкой, в которой происходило форматирование социалистических наций, в том числе и калмыков.

Именно политика коренизации позволила калмыкам преодолеть комплекс приниженности, сформировавшийся со временем у калмыков в результате 
самоликвидации Калмыцкого ханства в той политической, экономической и культурной ситуации, в которой они оказались.

Вопрос о достоинстве и чести актуализировался для калмыков из-за депортации в 1943 г и последующем проживании в регионах Сибири. Незаслуженно обвиненные в предательстве, лишенные не только земли, государственности, но даже этнонима, калмыки в Сибири стали изобретать новую идентичность, которая выстраивалась с помощью ресурса русского языка и самоотверженного труда. В условиях сибирской ссылки, лишенные гражданских прав ссыльные калмыки обрели новый габитус, в формировании которого депортация и травма депортации сыграли ключевые роли. Фронтовики, храбро сражавшиеся на фронтах Второй мировой войны, женщины и подростки, строившие стратегически важную железную дорогу Кизляр-Астрахань, по которой поступала нефть из Грозного для снабжения советских войск во время Сталинградской битвы, советские и партийные работники, обычные советские граждане-калмыки, старики и дети в один момент, после подписания Указа Президиума Верховного Совета СССР от 27 декабря 1943 г. «О ликвидации Калмыцкой АССР и образовании Астраханской области в составе РСФСР», стали предателями Родины и преступниками. Оказавшись даже не внизу социальной иерархии, а за ее пределами, ссыльные калмыки боролись не только за физическое выживание, но и социальное признание себя в качестве полноценных граждан советского государства. В этой борьбе они использовали ресурс русского языка, знание которого облегчало решить задачу признания, и ресурс самоотверженного труда на государство. Многие калмыки, несмотря на лишение прав, награждались грамотами и участием в значимых мероприятиях советского государства, например, во Всесоюзной сельскохозяйственной выставке.

Таким образом, в советское время габитус и, соответственно, ментальность калмыков радикально менялись под влиянием кардинальных преобразований хозяйства, системы политического, хозяйственного и социального управления. Огромную роль в этом сыграл советский пропагандистский аппарат. Калмыки обрели габитус советских граждан - строителей коммунизма. Вторая мировая война для калмыков стала катастрофой, так как обвиненные в коллаборационизме калмыки стали ссыльными. Соответственно поменялся их габитус, т. е. категории восприятия и оценивания, порождающие исполняемые ими практики.

\section{Постсоветский период}

В постсоветский период категории чести и достоинства, ставшие значимыми из-за депортации, обрели новые дополнительные смыслы. Политика суверенизации, провозглашенная президентом России Б. Н. Ельциным и реализованная первым президентом Калмыкии К. Н. Илюмжиновым, сопровождалась ростом национального самосознания. В сложной экономической и политической си- 
туации региона Северного Прикаспия и Кавказа, сложившейся в конце 1990-х и начале 2000-х гг., неизбежны были локальные межэтнические конфликты. Показательным с точки зрения значимости для калмыков категорий чести и достоинства был конфликт в селе Яндыки Астраханской области, разгоревшийся на бытовой почве, но по мере развития событий приобретавший характер межэтнических столкновений (Справка ..., 2006: Электр. ресурс). В разжигании конфликта участвовали разные акторы, в том числе астраханское казачество, использовавшее его в целях укрепления своих позиций. Мобилизация молодежи Калмыкии, ринувшейся защищать соплеменников в Яндыках, произошла во многом из-за ставших вновь значимыми для калмыков категорий чести и достоинства.

Недавний случай с осквернением статуи Будды в столице Калмыкии Элиста подтверждает не только значимость для калмыков категорий чести и достоинства, но и их мобилизующую силу. В апреле 2016 г. молодой дагестанец, приехавший из Махачкалы для участия в соревнованиях по борьбе, гуляя по городу, увидел статую Будды в ротонде близ центральной площади города. Он не только неуважительно отозвался о буддизме, но и осквернил ее. Все это было запечатлено и выложено им и его другом в социальные сети в Интернете. Молодые калмыки, узнав об этом из соцсетей, тут же собрались у гостиницы, где жили гости из Дагестана и потребовали публичных извинений и ареста борца. При этом участники конфликта со стороны калмыков не применяли силовых методов воздействия. Виновник был арестован, вскоре предан суду и осужден.

Данный конфликт свидетельствует не только о важности этих категорий для современных калмыков, но и об их мобилизующей силе, которую надо учитывать и в исследованиях, и в политической практике.

Большое влияние на формирование ментальности калмыков оказал буддизм и его заповеди: десять благих деяний - добродетелей, среди которых порицание зависти, не причинение зла. Представители имперской администрации в свое время порицали буддизм за то, что он формирует такие качества народа, как беспечность, нежелание думать о грядущем дне. Многие этнографы дореволюционной эпохи отмечали такие качества калмыков, как покорность, терпимость, дисциплинированность. Казалось, эти качества противоречат озабоченности своим достоинством и честью. На мой взгляд, здесь нет противоречия, так как все они определяются военно-кочевым образом жизни калмыков. Дисциплина и послушание - качества хороших воинов.

\section{Заключение}

Подводя итоги, следует сказать, что своеобразие ментальности российских калмыков определялось действием многих факторов. Прежде всего тем, что этногенез ойратских групп, из которых впоследствии в советское время была 
создана калмыцкая нация, был связан с военной службой, которую они несли в составе войск Чингис-хана. Начиная с XVI по XVIII вв. ойраты играли важную роль в политическом пространстве Центральной Азии, став имперским народом. Торгуды и дербеты, добровольно войдя в состав российского государства в период ее становления, продолжали оставаться «военным народом», но уже в другой империи - Российской. Военные практики, исполняемые в соответствии с системой принципов, организующих их, то есть согласно габитусу, в свою очередь инкорпорируются и функционируют как категории восприятия и оценки. Важнейшими среди них были категории чести, достоинства и дисциплины.

Калмыцкая автономия со временем была ограничена, что побудило большую часть калмыков во главе с наместником Убаши откочевать на исконные территории в Западной Монголии, ставшей к тому времени частью Цинской империи. Для оставшейся, меньшей части калмыков начался процесс аккультурации, осуществляемой ими вначале в форме сепаратизации, а затем маргинализации. Стремясь сохранить свой традиционный уклад калмыки, прежде всего степные, практически не развивали торговлю, земледелие, несмотря на то, что власти предпринимали разнообразные меры по их развитию. Миграция русского населения, усилившаяся особенно после отмены крепостного права, в конце концов привела к сокращению калмыцких земель. Обеднение скотоводов-калмыков, благосостояние которых напрямую зависело от действия природных факторов - засухи, буранов, нашествий саранчи и т. д., заставило их наниматься на рыбные промыслы и солеломные работы. Столкновение с новой для них промышленной и городской культурой, привело к смене стратегии аккультурации, на смену сепаратизации пришла маргинализация. А если учесть, что калмыки, за исключением донских и терских казаков, после заграничных походов русской армии 1813-1814 гг. на почти не призывались на военную службу и не участвовали в военных операциях, то это, естественно, привело к изменению габитуса воина. У калмыков стали формироваться совсем другие категории восприятия и оценки мира.

Радикальное изменение ментальности калмыков произошло в результате Великой Октябрьской революции, в результате которой был реализован проект модернизации. Революция стала катастрофой для хозяйства кочевников, потерявших в ходе гражданской войны почти весь скот. Это и стало причиной седентаризации. Вместе с тем, благодаря успешной модернизации калмыки не только стали образованным народом, но и нацией со своей государственностью. Смена исполняемых хозяйственных, политических, культурных практик сопровождалась сменой связанных с ними категорий.

Ключевым моментом в изменении ментальности калмыков стала депортация в Сибирь в 1943 г., когда калмыки были незаслуженно обвинены в коллаборационизме. Калмыки утратили не только государственность, но и перестали существовать как этнос. Репрессии подвергся даже этноним «калмык», вычер- 
кнутый не только из словарей и книга, но и стертый с памятника А. С. Пушкину, на котором была запечатлена цитата из его стихотворения «Я памятник себе воздвиг нерукотворный ...». Травма депортации стала причиной реставрации категорий чести и достоинства, столь важных для «военного» в прошлом народа. Вынужденные выстраивать свою новую идентичность, калмыки использовали такой ресурс, как доблестный труд и такой ресурс символического капитала, как русский язык, точнее, владение им.

В постперестроечный период начался новый этап в развитии ментальности калмыков, создававших новую нацию и новую идентичность. Важнейшими ресурсами в этом случае стали буддизм, военное прошлое и опыт депортации.

\section{СПИСОК ЛИТЕРАТУРЫ}

Авляев, Г. О., Санчиров, В. П. (1984). К вопросу о происхождении торгоутов и хошоутов в этническом составе средневековых ойратов Джунгарии (к проблеме этногенеза калмыков) // Проблемы этногенеза калмыков / отв. ред. Г. О. Авляев. Элиста : КНИИЯЛИ. 120 с. С. 43-58.

Бакаева, Э. П. (2017) Хошуты Калмыкии и Монголии: историкоэтнографический очерк [Электронный ресурс] // Новые исследования Тувы. № 1. URL: https://nit.tuva.asia/index.php/nit/article/view/698 (дата обращения: 13.06.2017). DOI: $10.25178 /$ nit.2017.1.6

Бакунин, В. М. (1995) Описание калмыцких народов, а особливо из них торгоутского, и поступки их ханов и владельцев. Элиста : Калм. кн. изд-во. 153 с.

Батыров, В. В. (2014) Очерки истории традиционной культуры калмыков последней трети XVIII - первой половины XIX вв. Элиста : КИГИ РАН. 226 с.

Бурдье, П. (2001) Практический смысл / пер. с фр.: А. Т. Бикбов, К. Д. Вознесенская, С. Н. Зенкин, Н. А. Шматко. СПб. : Алетейя. 562 с.

Бурдье, П. (1993) Социология политики / пер. с фр.; сост., общ. ред. и предисл. Н. А. Шматко. M.: Socio-Logos. 336 с.

Бурдье, П. (1994). Начала / пер. с фр.; сост., общ. ред. и предисл. Н. А. Шматко. M. : Socio-Logos. 288 c.

Голстунский, К. Ф. (1880) Монголо-ойратские законы 1640 г., дополнительные указы Галдан-Хун-Тайджия и законы, составленные для волжских калмыков при калмыцком хане Дондук-Даши / калм. текст с рус. пер. и прим. К. Ф. Голстунского. СПб. : Тип. Имп. Академии наук. 144 с.

Далай-лама : размышление о десяти неблагих деяниях (2009) [Электронный ресурс] // Сохраним Тибет! 14 октября. URL: http://savetibet.ru/2009/10/14/dalai_ lama.html (дата обращения: 20.06.2017). 
Дуброва, Я. П. (1998) Быт калмыков Ставропольской губернии. Элиста : Калм. кн. изд-во. 182 с.

Всесоюзная перепись населения 17.12.1926. Вып. 5. Возраст и грамотность. Европейская часть РСФСР, Белорусская ССР. (1928). М.: ЦСУ. [Электронный ресурс] // Государственная публичная библиотека России. URL: http://elib.shpl.ru/ru/ nodes/16530-vyp-5-vozrast-i-gramotnost-evropeyskaya-chast-rsfsr-belorusskayassr\#page/1/mode/grid/zoom/1 (дата обращения: 07.02.2017).

История Калмыкии с древнейших времен до наших дней (2009) : в 3-х т. Элиста : Изд. дом «Герел». Т. 3. 752 с.

Козлова, Н. Н. (1999) Социально-историческая антропология. М. : Ключ-С. 187 с.

Лебединский, А. (1927) К вопросу о вымирании калмыков // Калмыцкая степь. № 1-2. С. 104-145.

Митиров, А. Г. (1998) Ойраты-калмыки: века и поколения. Элиста : Калм. кн. изд-во. 384 с.

Миллер, Г. Ф. (1993) Актовые источники по истории Сибири XVI-XVIII вв.: описи копийных книг : в 2 т. / сост. А. Х. Элерт. Новосибирск : Сибирский хронограф. Т. І. 552 с.

Михайловский, Л. (1928) О нацменьшинствах Калмыцко-Базаринского улуса // Калмыцкая степь. № 1 (4). С. 67-75.

Немирович-Данченко, В. И. (1877). По Волге. (Очерки и впечатления летней поездки). СПб. : И.Л. Тузов. 404 с.

Нефедьев, Н. А. (1834) Подробные сведения о волжских калмыках // Журнал Министерства внутренних дел. Ч. 12. № 6. 290 с.

Огородников, П. (1878) На пути в Персию. Прикаспийские провинции ее. СПб. : Тип. М. И. Попова. 331 с.

Очерки истории Калмыцкой АССР. Эпоха социализма (1970) / гл. ред. Н. В. Устюгов. М. : Наука. 432 с.

Очиров А. В. (2008) Развитие торговли, ремесла, рыболовства и соледобычи в Калмыцкой степи после 1892 г. // Известия Алтайского университета. Вып. 4-3. C. 203-204.

Пахолова, И. В. (2015) От «Чужака» к «Другому»: проблема взаимодействия сообществ в феноменологии «чужого» // Аспирантский вестник Поволжья. № 7-8. С. 90-94.

Пахолова, И. В. (2011) Гостеприимство и утрата: социокультурный опыт «чужого». Самара : Изд-во «Самарский университет». 160 с. 
Поволжье - «внутренняя окраина» России: государство и общество в освоении новых территорий (кон. XVI-нач. XX вв.) (2007) / под ред. Э. Л. Дубмана, П. С. Кабытова. Самара : Самарское отд-ние Литфонда. 327 с.

Прозрителев, Г. Н. (1912). Военное прошлое наших калмыков. Репр. изд. Элиста : Изд-во «Санан». 384 с.

Р-ва, Зинаида [Е. Ган] (1838) Утбалла // Библиотека для чтения. Т. 26. С. 141-244.

Самарские губернские ведомости, Часть неофициальная (1854) (газета). № 12 . Март, 20. С. 80-81.

Санчиров, В. П. (1996) О происхождении этнонима торгут и народа, носившего это имя // Монголо-бурятские этнонимы : сб. статей / отв. ред. А. Очир, Б. Р. Зориктуев. Улан-Удэ : БНЦ СО РАН. 107 с. С. 31-50.

Справка о событиях в селе Яндыки Астраханской области (ПЦ «Мемориал») (2006) [Электронный ресурс] // Международный мемориал. 17 августа. URL: http://old.memo.ru/hr/discrim/ver1/m57377.htm (дата обращения: 15.06.2017).

Хойт, С. К. (2015) Этническая история ойратских групп (рукопись) [Электронный ресурс] // Российский гуманитарный научный фонд. URL. http://www.rfh. ru/downloads/Books/154193053.pdf (дата обращения: 15.06.2017).

Чингис-хан.История завоевателя мира, записанная Ала ад-дином Ата-Меликом Джувайни (2004) / пер. с англ. Е. Е. Харитоновой. М. : Магистр-Пресс. 688 с.

Armstrong, J. A. (1982) Nations before nationalism. Chapel Hill: University of North Carolina Press. 411 p.

Grousset, R. (1980) L'empire des steppes: Attila, Gengis-Khan, Tamerlan. Paris: Payot. 651 p.

Grousset, R. (1970) The Empire of Steppes. A History of Central Asia / Transl. from French by N. Walford. Rutgers University. 687 p.

Hirsch, F. (2005) Empire of Nations. Ethnographic Knowledge and the Making of the Soviet Union. Ithaca, NY: Cornell University Press. 367 p.

Khodarkovsky, M. (1992). Where Two Worlds Met. The Russian State and the Kalmyk Nomads, 1600-1771. Cornell University Press, Ithaca and London. 278 p.

Lane, G. (2006) Daily life in the Mongol empire. Greenwood Press, Westport, CT. $312 \mathrm{p}$.

Lee,Joo-Yup.(2016)Were the historical Oirats “Western Mongols”? An examination of their uniqueness in relation to the Mongols [Электронный ресурс] // Études Mongoles \& Sibériennes, Centrasiatiques \& Tibétaines. № 47. P. 2-26. URL: http:// emscat.revues.org/2820 (дата обращения: 12.01.17) DOI: 10.4000/emscat.2820

Дата поступления: 20.06.2017 2. 


\section{REFERENCES}

Avliaev, G. O. and Sanchirov, V. P. (1984). K voprosu o proiskhozhdenii torgoutov i khoshoutov v etnicheskom sostave srednevekovykh oiratov Dzhungarii (k probleme etnogeneza kalmykov) [On the issue of origin of the Torghuts and Khoshuts in the ethnic composition of medieval Oirats of Dzungaria (to the problem of the ethnogenesis of the Kalmyks)]. In: Problemy etnogeneza kalmykov [Problems of ethnogenesis of the Kalmyks]. Ed. by G. O. Avliaev. Elista, KNIIIaLI. 120 p. Pp. 43-58. (In Russ.)

Bakaeva, E. P. (2017) Khoshuty Kalmykii i Mongolii: istoriko-etnograficheskii ocherk [The Khoshuts of Kalmykia and Mongolia: a historical and ethnographical overview]. The New Research of Tuva, no. 1 [online] Available at: https://nit.tuva.asia/ nit/article/view/698 (access date: 13.06.2017). DOI: 10.25178/nit.2017.1.6 (In Russ.)

Bakunin, V. M. (1995) Opisanie kalmytskikh narodov, a osoblivo iz nikh torgoutskogo, i postupki ikh khanov $i$ vladel'tsev [A description of the Kalmyk peoples, and especially of Torghuts, and the actions of their khans and owners]. Elista, Kalm. kn. izd-vo. 153 p. (In Russ.)

Batyrov, V. V. (2014) Ocherki istorii traditsionnoi kul'tury kalmykov poslednei treti $X V I I I-$ pervoi poloviny XIX vv. [Essays on the history of the traditional culture of the Kalmyks in the last thirty years of 18th and the first half of 19th centuries]. Elista, KIGI RAN. 226 p. (In Russ.)

Bourdieu, P. (2001) Prakticheskii smysl [Practical reason], transl. from Fr. by A. T. Bikbov, K. D. Voznesenskaia, S. N. Zenkin and N. A. Shmatko. St. Petersburg, Aleteiia. 562 p. (In Russ.).

Bourdieu, P. (1993) Sotsiologiia politiki [Sociology of politics], transl. from Fr., comp., ed. and notes by N. A. Shmatko. Moscow, Socio-Logos. 336 p. (In Russ.).

Bourdieu, P. (1994). Nachala [Beginnings], transl. from Fr., comp., ed. and notes by N. A. Shmatko. Moscow. Socio-Logos. 288 p. (In Russ.).

Golstunskii, K. F. (1880) Mongolo-oiratskie zakony 1640 g., dopolnitel'nye ukazy Galdan-Khun-Taidzhiia i zakony, sostavlennye dlia volzhskikh kalmykov pri kalmytskom khane Donduk-Dashi [The Mongol-Oirat laws of 1640, additional decrees by GaldanHoon-Taijiya and laws compiled for the Volga Kalmyks under the Kalmyk Khan DondukDasha], transl. by K. F. Golstunskii. St. Petersburg, Tip. Imp. Akademii nauk. 144 p. (In Russ.)

Dalai-lama : razmyshlenie o desiati neblagikh deianiiakh [The Dalai Lama : a meditation about the 10 bad deeds] (2009). Save Tibet! 14 October [online] Available at: http://savetibet.ru/2009/10/14/dalai_lama.html (access date: 20.06.2017). (In Russ.)

Dubrova, Ia. P. (1998) Byt kalmykov Stavropol'skoi gubernii [Everyday life of the Kalmyks of the Stavropol province]. Elista, Kalm. kn. izd-vo. 182 p. (In Russ.) 
Vsesoiuznaia perepis' naseleniia 17.12.1926. Vyp. 5. Vozrast i gramotnost'. Evropeiskaia chast' RSFSR, Belorusskaia SSR [Census of 17.12.1926. Vol. 5. Age and literacy. The European part of the RSFSR, Byelorussian SSR] (1928). M.: TsSU. Gosudarstvennaia publichnaia biblioteka Rossii [online] Available at: http://elib. shpl.ru/ru/nodes/16530-vyp-5-vozrast-i-gramotnost-evropeyskaya-chast-rsfsrbelorusskaya-ssr\#page/1/mode/grid/zoom/1 (access date: 07.02.2017). (In Russ.)

Istoriia Kalmykii s drevneishikh vremen do nashikh dnei [The history of Kalmykia from ancient times to the present day] (2009) : in 3 vols. Elista, Izd. dom «Gerel». Vol. 3.752 p. (In Russ.)

Kozlova, N. N. (1999) Sotsial'no-istoricheskaia antropologiia [Socio-historical anthropology]. Moscow, Kliuch-S. 187 p. (In Russ.)

Lebedinskii, A. (1927) K voprosu o vymiranii kalmykov [The question of the extinction of the Kalmyks]. Kalmytskaia step', no. 1-2, pp. 104-145. (In Russ.)

Mitirov, A. G. (1998) Oiraty-kalmyki: veka i pokoleniia [Oirats-Kalmyks: centuries and generations]. Elista, Kalm. kn. izd-vo. 384 p. (In Russ.)

Miller, G. F. (1993) Aktovye istochniki po istorii Sibiri XVI-XVIII vv.: opisi kopiinykh knig [Acts and legislative sources of the history of Siberia in the 16th-18th centuries: the inventory scale books]: in 2 b. / comp. by A. Kh. Elert. Novosibirsk, Sibirskii khronograf. Vol. I. 552 p. (In Russ.)

Mikhailovskii, L. (1928) O natsmen'shinstvakh Kalmytsko-Bazarinskogo ulusa [On the national minorities of Kalmyk-Bazarin ulus]. Kalmytskaia step', no. 1 (4), pp. 6775. (In Russ.).

Nemirovich-Danchenko, V.I.(1877) Po Volge.(Ocherki i vpechatleniia letnei poezdki) [Along The Volga. (Essays and impressions of a summer trip)]. St. Petersburg, I. L. Tuzov. 404 p. (In Russ.).

Nefed'ev, N. A. (1834) Podrobnye svedeniia o volzhskikh kalmykakh [Detailed information about the Volga Kalmyks]. Zhurnal Ministerstva vnutrennikh del, vol. 12, no. 6. 290 p. (In Russ.).

Ogorodnikov, P. (1878) Na puti v Persiiu. Prikaspiiskie provintsii ee [On the way to Persia: Its Caspian provinces]. St. Petersburg, Tip. M. I. Popova. 331 p. (In Russ.).

Ocherki istorii Kalmytskoi ASSR. Epokha sotsializma [Essays on the history of the Kalmyk ASSR. The era of socialism] (1970) / ed. by N. V. Ustiugov. Moscow, Nauka. 432 p. (In Russ.).

Ochirov A. V. (2008) Razvitie torgovli, remesla, rybolovstva i soledobychi v Kalmytskoi stepi posle $1892 \mathrm{~g}$. [The development of trade, crafts, fishing and salt production in the Kalmyk steppe after 1892]. Izvestiia Altaiskogo universiteta, vol. 4-3, pp. 203-204. (In Russ.). 
Pakholova, I. V. (2015) Ot «Chuzhaka» k «Drugomu»: problema vzaimodeistviia soobshchestv v fenomenologii «chuzhogo» [From the «Stranger» to the «Other»: the problem of interaction between communities in the phenomenology of the "alien"]. Aspirantskii vestnik Povolzh'ia, no. 7-8, pp. 90-94. (In Russ.).

Pakholova, I. V. (2011) Gostepriimstvo i utrata: sotsiokul'turnyi opyt «chuzhogo» [Hospitality and bereavement: a sociocultural experience of «alien»]. Samara, Izd-vo «Samarskii universitet». 160 p. (In Russ.).

Povolzh'e - «vnutrenniaia okraina» Rossii: gosudarstvo i obshchestvo $v$ osvoenii novykh territorii (kon. XVI-nach. XX vv.) [The Volga region - the «inner suburb» of Russia: state and society in the development of new territories (late 16th - early 20th centuries)] (2007) / ed. by E. L. Dubman and P. S. Kabytov. Samara, Samarskoe otd-nie Litfonda. 327 p. (In Russ.).

Prozritelev, G. N. (1912). Voennoe proshloe nashikh kalmykov [The military past of our Kalmyks]. Reprint. Elista, Izd-vo «Sanan». 384 p. (In Russ.).

R-va, Zinaida [E. Gan] (1838) Utballa. In: Biblioteka dlia chteniia, vol. 26, pp. 141244. (In Russ.).

Samarskie gubernskie vedomosti, Chast' neofitsial'naia (1854) (newspaper), no. 12. Mart 20. Pp. 80-81. (In Russ.).

Sanchirov, V.P. (1996) O proiskhozhdenii etnonima torgut i naroda, nosivshego eto imia [On the origin of the ethnonym of Torghut and the people, who bore this name]. In: Mongolo-buriatskie etnonimy [Mongol-Buryat ethnonyms]: collection of articles / ed. by A. Ochir and B. R. Zoriktuev. Ulan-Ude, BNTs SO RAN. 107 p. Pp. 31-50. (In Russ.).

Spravka o sobytiiakh v sele Iandyki Astrakhanskoi oblasti (PTs «Memorial») [A Note about the events in the village of Yandyki, Astrakhan region ("Memorial" human rights center)] (2006). Mezhdunarodnyi memorial, August 17 [online] Available at: http://old.memo.ru/hr/discrim/ver1/m57377.htm (access date: 15.06.2017). (In Russ.).

Khoit, S. K. (2015) Etnicheskaia istoriia oiratskikh grupp [Ethnic history of Oirat groups] (manuscript). Rossiiskii gumanitarnyi nauchnyi fond [online] Available at: http://www.rfh.ru/downloads/Books/154193053.pdf (access date: 15.06.2017). (In Russ.).

Chingis-khan. Istoriia zavoevatelia mira, zapisannaia Ala ad-dinom Ata-Melikom Dzhuvaini [Genghis Khan. The history of the world conqueror, written by Ala ad-din Ata-Malik Dzhuvaini] (2004) / transl. from English by E. E. Kharitonova. Moscow, Magistr-Press. 688 p. (In Russ.).

Armstrong, J. A. (1982) Nations before nationalism. Chapel Hill, University of North Carolina Press. 411 p. 
Grousset, R.(1980) L'empire des steppes: Attila, Gengis-Khan, Tamerlan. Paris, Payot. 651 p. (In Fr.).

Grousset, R. (1970) The Empire of Steppes. A History of Central Asia / transl. from French by N. Walford. Rutgers University. 687 p.

Hirsch, F. (2005) Empire of Nations. Ethnographic Knowledge and the Making of the Soviet Union. Ithaca, NY: Cornell University Press. 367 p.

Khodarkovsky, M. (1992). Where Two Worlds Met. The Russian State and the Kalmyk Nomads, 1600-1771. Cornell University Press, Ithaca and London. 278 p.

Lane, G. (2006) Daily life in the Mongol empire. Greenwood Press, Westport, CT. $312 \mathrm{p}$.

Lee,Joo-Yup.(2016) Were the historical Oirats “Western Mongols”? An examination of their uniqueness in relation to the Mongols. Etudes Mongoles \& Sibériennes, Centrasiatiques \& Tibétaines, no. 47, pp. 2-26 [online] Available at: http://emscat. revues.org/2820 (access date: 12.01.17). DOI: 10.4000/emscat.2820

Submission date: 20.06.2017.

\section{Для цзитирования:}

Четырова Л. Б. Ментальность калмыков: истоки и причины изменений [Электронный ресурс] // Новые исследования Тувы. 2017, № 3. URL: https:/nit.tuva.asia/nit/ article/view/730 (дата обращения: дд.мм.гг.). DOI: 10.25178/nit.2017.3.8

\section{For citation:}

Chetyrova L. B. The Mindset of Kalmyks: origins and causes of alterations. The New Research of Tuva, 2017, no. 3 [on-line] Available at: https://nit.tuva.asia/nit/article/view/730 (accessed: ...). DOI: 10.25178/nit.2017.3.8 